\section{Thinning and retreat of Xiao Dongkemadi glacier, Tibetan Plateau, since 1993}

It is important to monitor glaciers and ice caps for their contribution to sea-level change and as sensitive indicators of local climate (Hoelzle and others, 2003; Oerlemans, 2005; Kaser and others, 2006; Meier and others, 2007). However, glacier mass-balance estimates determined by the direct glaciological method once or twice per year contribute very little to sea-level information (Braithwaite, 2002), and more data from measured glaciers are necessary to better extrapolate to particular glacier regions to examine their contribution (Hoelzle and others, 2003; Arendt and others, 2006; Haeberli and others, 2007a). Ice-elevation changes derived from multi-period digital elevation models (DEMs) offer one method of evaluating glacier mass balance through time. However, this method does not produce detailed interannual records like the traditional massbalance technique (Pope and others, 2007; Berthier and others, 2008).

Xiao Dongkemadi glacier (XDG) is located near Tanggula Pass (the highest point on the Lanzhou-Lhasa road 5206 ma.s.l.), central Tibetan Plateau $\left(33^{\circ} 04^{\prime} \mathrm{N}, 92^{\circ} 04^{\prime} \mathrm{E}\right)$. Here, glacier mass balance directly reflects the glacier's response to local climate change, and glacier changes on the Tibetan Plateau strongly influence human welfare since water supplies in this arid/semi-arid region are predominantly from glacier melt. Due to its remote location, the mass balance of XDG has been monitored discontinuously since 1988 by the direct glaciological method ( $\mathrm{Pu}$ and others, 1998; Yao and others, 2007). Measured annual mass balances were 525, 49.4, -190.9, 375.8, 211.4, -517.9, $-597,-506.4,370$ and $-670 \mathrm{~mm}$, respectively, for the years 1989-98. Mass balance has been negative most of the time since 1993. Here, we present results from a topographic map in 1969, observations between 1989 and 1998, and real-time kinematic (RTK) global positioning system (GPS) surveys in October 2007.

We have GPS measurements covering almost the entire glacier on 13 October 2007. We have surveyed 722 points on XDG within the glacier area, $1.20 \mathrm{~km}^{2}$ (Fig. 1), at a sampling spacing of 25-50 m. All GPS data, measured with respect to the Universal Transverse Mercator (UTM) World Geodetic System 1984 ellipsoidal elevation (WGS84), were re-projected and transformed to the 1954 Beijing Geodetic Coordinate system (BJ54) GEOID (datum level is Yellow Sea mean sea level at Qingdao Tidal Observatory in 1956) using LandTop software version 2.0.5.1. The method of measuring a surface point in RTK differential mode results in a survey error of $\sim 0.10-0.30 \mathrm{~m}$ for geodetic-quality GPS receivers (Rivera and others, 2005). The error using a seven-parameter space transform model is $<0.002 \mathrm{~m}$ (Wang and others, 2003). We interpolated our GPS data to contours at $5 \mathrm{~m}$ intervals to generate a 2007 DEM (DEM2007) with a pixel resolution of $10 \mathrm{~m}$, supported by Geographic Information System (GIS)-based methodology.

Another DEM for 1969 (DEM1969), with respect to BJ54, was produced by digitizing the $20 \mathrm{~m}$ interval contours and spot heights from a topographic map, interpolated and filtered with $10 \mathrm{~m}$ cell size, using Arcmap software. The map was derived from aerial photographs acquired in 1969 by the Chinese military geodetic service. The systematic errors of DEM1969 were $< \pm 11 \mathrm{~m}$ over slopes $<15^{\circ}$ and $< \pm 19 \mathrm{~m}$ over slopes $>25^{\circ}$ (State Bureau of Surveying and Mapping,
2007). However, the differences between DEM1969 and DEM2007 are within $\pm 5.2 \mathrm{~m}$ (with standard deviation, $2.4 \mathrm{~m}$ ), ascertained by comparison at nine random independent points selected in surrounding non-glacial areas under $5600 \mathrm{~m}$ a.s.l.

Comparing the two DEMs (2007 with 1969), the mean ice elevation over XDG decreased by $\sim 7.92 \mathrm{~m}$, or $0.21 \mathrm{~m} \mathrm{a}^{-1}$. The largest decrease in ice elevation of $63.51 \mathrm{~m}$ was at the tongue, corresponding to a retreat of the glacier terminus of $\sim 77 \mathrm{~m}$. In addition, there was considerable variability of the elevation change with height (Fig. 1). The elevation change over the full study period was large (about -15 to $-63.51 \mathrm{~m}$ ) below $\sim 5500$ ma.s.l. It was negative between 5500 and $5600 \mathrm{~m}$ a.s.l., but slightly positive near $5650 \mathrm{ma}$ a.s.l. As a consequence the equilibrium line altitude (ELA) position, estimated to be $5650 \mathrm{~m}$ a.s.l. in 2007 for zero balance, is $\sim 105 \mathrm{~m}$ higher than in 1993 (5545 ma.s.I.) (Pu and others, 1998). The ice-elevation changes are complex above $5650 \mathrm{~m}$ a.s.l., which is in the accumulation region. However, the error increases along with increased slope in parts of the accumulation region.

Summarizing, XDG has experienced two main change phases during the period 1969-2007. The elevation of XDG increased by an average of $\sim 4.60 \mathrm{~m}$, or $0.19 \mathrm{~m} \mathrm{a}^{-1}$, corresponding to a tongue advance of $16.9 \mathrm{~m}$ from 1969 to 1993 (Pu and others, 1998; Yao and others, 2002). After 1993, the ice surface elevation decreased $\sim 1.62 \mathrm{~m}\left(0.54 \mathrm{~m} \mathrm{a}^{-1}\right)$ from 1993 to 1996 and decreased by $\sim 11.0 \mathrm{~m}\left(1.1 \mathrm{~m} \mathrm{a}^{-1}\right)$ from 1996 to 2007, corresponding to a tongue retreat of $93.9 \mathrm{~m}$ between 1993 and 2007. These results support the finding that the observed acceleration trend corresponds to similar developments elsewhere and even at a global scale (Haeberli and others, 2007b). The first phase may be explained by a drop in summer temperature. Between 1969 and 1993 the mean temperature at TuoTuo weather station $\left(34^{\circ} 13^{\prime} \mathrm{N}, 92^{\circ} 26^{\prime} \mathrm{E} ; 4533.1 \mathrm{~m}\right.$ a.s.l.) was $0.12^{\circ} \mathrm{C}$ lower than the 1957-2002 mean temperature. Associated with the temperature reduction, there was a reduction in the ablation on XDG, resulting in the advance of the glacier tongue. The second phase was triggered by summer warming by $\sim 0.65^{\circ} \mathrm{C}$ after 1993 , accompanied by increased annual precipitation, causing negative surface mass balance, which led to glacier retreat.

\section{ACKNOWLEDGEMENTS}

We thank Y. Baisheng for helpful suggestions. This work was supported by the Key Programs of the Chinese Academy of Sciences (grant KZCX2-YW-301-1), a grant from the Major State Basic Research Development Program of China (973 Program) (No. 2007CB411506), the Ministry of Science and Technology of the People's Republic of China (grant 2006FY110200) and National Natural Science Foundation of China (grant 40601022).

$\begin{array}{lr}\text { State Key Laboratory of } & \text { SHANGGUAN Donghui } \\ \text { Cryospheric Science, } & \text { LIU Shiyin } \\ \text { Cold and Arid Regions } & \text { DING Yongjian } \\ \text { Environmental and Engineering } & \text { ZHANG Yingsong } \\ \text { Research Institute, } & \text { DU Erji } \\ \text { Chinese Academy of Sciences, } & \text { WU Zhen }\end{array}$

E-mail:dhguan@Izb.ac.cn

12 September 2008 


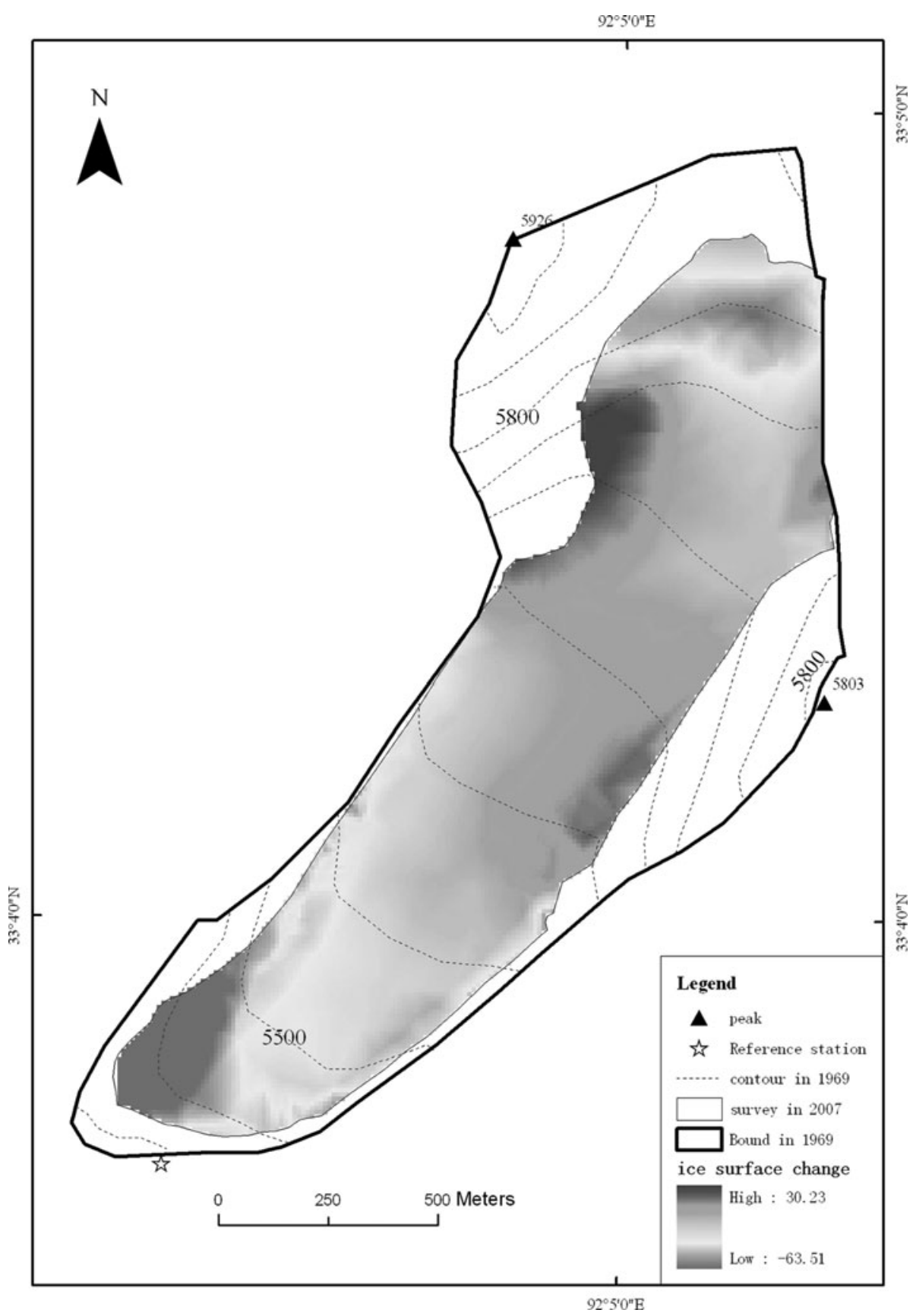

Fig 1. XDG ice-elevation changes based on DEMs developed from a topographic map (1969) and kinematic global positioning system (GPS) data (2007).

\section{REFERENCES}

Arendt, A. and 7 others. 2006. Updated estimates of glacier volume changes in the western Chugach Mountains, Alaska, and a comparison of regional extrapolation methods. J. Geophys. Res., 111(F3), F03019. (10.1029/2005JF000436.)

Berthier, E. and T. Toutin. 2008. SPOT5-HRS digital elevation models and the monitoring of glacier elevation changes in North-West Canada and South-East Alaska. Remote Sens. Environ., 112(5), 2443-2454.

Braithwaite, R.J. 2002. Glacier mass balance: the first 50 years of international monitoring. Progr. Phys. Geogr., 26(1), 76-95.

Haeberli, W., M. Hoelzle and M. Zemp, eds. 2007a. Glacier Mass Balance Bulletin No. 9 (2004-2005). Zürich, World Glacier Monitoring Service.

Haeberli, W., M. Hoelzle, F. Paul and M. Zemp. 2007b. Integrated monitoring of mountain glaciers as key indicators of global climate change: the European Alps. Ann. Glaciol., 46, 150-160.
Hoelzle, M., W. Haeberli, M. Dischl and W. Peschke. 2003. Secular glacier mass balances derived from cumulative glacier length changes. Global Planet. Change, 36(4), 295-306.

Kaser, G., J.G. Cogley, M.B. Dyurgerov, M.F. Meier and A. Ohmura. 2006. Mass balance of glaciers and ice caps: consensus estimates for 1961-2004. Geophys. Res. Lett., 33(19), L19501. (10.1029/2006GL027511.)

Meier, M.F. and 7 others. 2007. Glaciers dominate eustatic sealevel rise in the 21st century. Science, 317(5841), 1064-1067.

Oerlemans, J. 2005. Extracting a climate signal from 169 glacier records. Science, 308(5722), 675-677.

Pope, A., T. Murray and A. Luckman. 2007. DEM quality assessment for quantification of glacier surface change. Ann. Glaciol., 46, 189-194.

$\mathrm{Pu}$, J.C. and T.D. Yao. 2002. Mass balance and glacial variation in last decades. In Yao, T. (ed.) Dynamical feature of cryosphere in middle Tibetan Plateau. Beijing: Geological Press, 207-233. [In Chinese.] 
Pu, J., Z. Su, T. Yao and Z. Xie. 1998. Mass balance on Xiao Dongkemadi glacier and Hailuogou glacier. J. Glaciol. Geocryol., 20(4), 408-412.

Rivera, A., G. Casassa, J.L. Bamber and A. Kääb. 2005. Iceelevation changes of Glaciar Chico, southern Patagonia, using ASTER DEMs, aerial photographs and GPS data. J. Glaciol., 51(172), 105-112.

State Bureau of Surveying and Mapping. 2007. Technical rules for producing digital products of 1:10000 1:50000 fundamental geographic information. Part 1: Digital line graphs (DLG), $\mathrm{CH} / \mathrm{T}$ 1015.1-2007.

Wang, J.X., J. Wang and C. P. Lu. 2003. Problem of coordinate transformation between WGS-84 and BEIJING 54. J. Geod. Geodyn., 23(3), 70-73. [In Chinese.]

Yao, T., J. Pu, A. Lu, Y. Wang and W. Yu. 2007. Recent glacial retreat and its impact on hydrological processes on the Tibetan Plateau, China, and surrounding regions. Arct. Antarct. Alp. Res., 39(4), 642-650. 